\title{
The Relationship between Risk Management and Profitability of Commercial Banks in Albania
}

\author{
${\text { Arjeta Hallunovi }{ }^{*} \text {--- Miranda Berdo }}^{2}$ \\ ${ }^{*}$ Lecturer, Business Faculty, Aleksander Moisiu University, Durres, Albania \\ Email:arjeta26@yahoo.com \\ ${ }^{2}$ Department of Performance Audit, Albania Supreme Audit Institution, Albania
}

\begin{abstract}
Profitability is an indicator of the capacity of commercial banks to cope with their risk and/or capital growth, showing their competitiveness and measuring the quality of management. Credit risk is one of the significant risks of commercial banks by the nature of their activities. By effectively managing the exposure of commercial banks to credit risk, they not only support the viability and profitability of their business but also contribute to the system, stability and efficient allocation of capital to the economy. The purpose of the study was to determine whether there is a relationship between credit risk management and profitability in commercial banks in Albania. In this paper, there are four variables: ROA and ROE are the dependent variables, whereas non-performing loans (NPLs) and capital adequacy (CAR) are the independent variables. The main source of data collection are the annual reports for a 7year period (2008-2015) by the Albanian Association of Banks. For quantitative data analysis, multiple regression model was used (SPSS).
\end{abstract}

Keywords: Albania, Commercial banks, Profitability, ROE, ROA.

Licensed: This work is licensed under a Creative Commons Attribution 4.o License.

\section{Introduction}

As a critical part of financial systems, banks play an important role in contributing to the country's economic development and also the functioning of an economy (Pasiouras and Kosmidou, 2007). If the banking industry is not working well, the effect on the economy can be large and broad. Efficiency of commercial banks in managing their risk in different business cycles can lead to improved losses and crises between them (Alexandri and Santoso, 2015). Typically, Ameur and Mhiri (2013) defined risk as an exposure to a proposal for which one is uncertain. While risk management is the process of risk identification, risk analysis and assessment, risk audit and risk management to control the financial exposure of the commercial bank, based on study of Chinoda (2014). Banks are exposed to risks, while credit risk is one of the threats to the credibility of commercial banks (Panda and Hota, 2014).

The study of profitability is important not only because of the information it provides about the health of the economy every year, but also because profits are a key determinant of growth and employment in the medium term according to Ongore and Kusa (2013). Banking performance assessment is a process that requires special attention from several factors. In developing countries where our country is classified, it is very important to have good, sustainable, fast economic progress, thus increasing the benefits of all financial institutions (Suzuki and Sastrosuwito, 2014). It is imperative for every country to have the banking sector, well structured and profitable, in such a way as to be competitive and successful (Saeed, 2016). The stability of the financial system depends on the profitability of the banking sector. Profitability is an indicator of the 
bank's capacity to cope with the risk and increase its capital. Profitability is used to determine the progress of a business. Profitability determinants have been studied and researched even though the profitability definition varies between studies (Sayilgen and Yildirim, 2009).

\section{Literature Review}

Many studies conducted by different authors have concluded that credit risk management is the main determinant of bank profitability (Shrestha, 2017). But there are also studies that have proven the opposite. Awoke (2014) has made a study on bank profitability, where it has come to the conclusion that there is a positive relationship between profitability and liquidity in 12 European, North American and Australian banks. Meanwhile Gitau et al. (2017) have concluded, according to their study, that these two variables have negative relationship. Gizaw et al. (2015) in their empirical study reported that US banks in the 1980 s had a strong positive correlation between the equity ratio and profitability but this relationship may be negative in certain situations. In another study, Abdullah et al. (2014) found the same result for commercial banks in the United Kingdom during 2000-2005. Another study conducted by Frederick (2014) examined the relationship between credit risk and liquidity risk in relation to the profitability of banks in Indonesia and revealed a negative credit risk effect and a positive effect of liquidity risk on bank profitability.

Ali et al. (2011) in their study showed that the management of credit risk had an effect on the profitability of commercial banks taken in the study. As to the two indicators taken as representatives of credit risk management, it turned out that NPL has a greater impact than the CAR in one of the ROE profit determinants. This effect is different in different commercial banks. Gul et al. (2011) concluded in their study that credit risk management has a positive impact on the profitability of commercial banks. The same conclusion was found also by Isik et al. (2016), where non-performing loans, loan loss provisions and capital adequacy have a significant impact on the profitability of commercial banks in Ethiopia. In other studies of this nature Ishak et al. (2016) reviewed the factors that affect the performance of Islamic commercial banks. It was reported that the high level of financial leverage and the high credit rate in relation to assets showed a positive correlation with profitability. Also Naceur (2003) concluded in a positive relationship between the credit risk of Swiss commercial banks and the capital rate during 1989-1995. Kosmidou (2008) study the factors that influence the profitability of commercial banks in Europe. He found a positive relationship between CAR and profitability. Previous studies also reflected a close relationship between NPL and credit risk management.

\section{Empirical Analysis}

In order to answer the hypothesis of the study, an econometric model has been built to identify and measure the variable that most affects the commercial banks' profitability in Albania. Estimated multiple regression equation:

$\hat{y}=b_{0}+b_{1} x_{1}+b_{2} x_{2}+\ldots b_{p} x_{p}$

This is the estimated multiple regression equation, which determines the correlation between variables taken in the study ( $\mathrm{Li}$ and Zou, 2014). Where $\mathrm{b}_{0}$ is the constant term of the model and $\mathrm{b}_{1}, \mathrm{~b}_{2}$ are the regression function coefficients. Using this model and comparing the coefficients next to each independent variable, it will be found which of the variables affects the profitability of the banks.

Table-1. Summary of the econometric model for dependent variables (ROA/ROE).

\begin{tabular}{c|c|c|c|c} 
Model Summary & \multicolumn{1}{l}{ Std. Error of the Estimate } \\
\hline Model & R & R Square & Adjusted R Square & .26319 \\
\hline 1 & .778 & .606 & .579 & 3.08454 \\
\hline 2 & .815 & .665 & .642 & .
\end{tabular}

According to the results in Table 1, the test has calculated that the Adjusted R Square is 0.579 ie $57.9 \%$ of the ROA variable explained by the model. Capital adequacy and non-performing loans account for $57.9 \%$ of changes in profitability of commercial banks measured by return on assets. Meanwhile, $42.1 \%$ is the unexplained part, which may be explained by other factors that are not included in the model. Correlation coefficient $\mathrm{R}=0.778$ means that there is a strong linear relationship between the variables ROA and independent NPL and CAR variables. While the test has calculated that the Adjusted R Square is 0.642 ie $64.2 \%$ of the ROE variable is explained by the model. That is, capital adequacy and non-performing loans explain $64.2 \%$ of changes in banks' profitability measured by return on equity. Meanwhile, $35.8 \%$ is the unexplained part, which may be explained by other factors that are not included in the model. Correlation coefficient $\mathrm{R}=0.815$ means there is a strong linear relationship between the ROE-dependent variables and the independent NPL and CAR variables. 
Table-2. ANOVA Table.

\begin{tabular}{l|l|l|l|l|l|l}
\multicolumn{2}{l|}{ ANOVA $^{\mathbf{a}}$} \\
\hline Model & Sum of Squares & Df & Mean Square & F & Sig. \\
\hline \multirow{4}{*}{1} & Regression & 3.088 & 2 & 1.544 & 22.290 & .000 \\
\cline { 2 - 7 } & Residual & 2.009 & 29 & .069 & & \\
\cline { 2 - 7 } & Total & 5.097 & 31 & & & .000 \\
\hline \multirow{2}{*}{2} & Regression & 547.018 & 2 & 273.509 & 28.747 &. \\
\cline { 2 - 7 } & Residual & 275.917 & 29 & 9.514 & & \\
\cline { 2 - 7 } & Total & 822.935 & 31 & & & \\
\hline
\end{tabular}

According to the results in Table 2, the two hypotheses are confirmed for the importance of the first model as a whole.

Ho: Independent variables, NPL and CAR do not affect the dependent variable ROA.

Ha: Independent variables, NPL and CAR affect the dependent variable ROA.

For $\alpha=0.05$

$\mathrm{P}=0.000<0.05 \rightarrow \mathrm{Ho} \downarrow \rightarrow \mathrm{Ha} \uparrow$

So, the basic hypothesis falls down and alternative hypotheses are accepted. It is concluded that the model is important in its entirety, independent variables, therefore, non-performing loans and capital adequacy affect the dependent variable of return on assets. To prove the hypothesis is also found critical value through Fisher distribution.

$\mathrm{Fc}=\mathrm{F}_{\mathrm{k}, \mathrm{n}-\mathrm{k}-1, \alpha}=\mathrm{F}_{2,29,0.05}=3.3277$

According to the results in Table 2, the two hypotheses are confirmed for the importance of the second model as a whole.

Ho: Independent variables, NPL and CAR do not affect the dependent variable ROE.

$H a$ : Independent variables, NPL and CAR affect the dependent variable ROE.

For $\alpha=0.05$

$\mathrm{P}=0.000<0.05 \rightarrow \mathrm{Ho} \downarrow \rightarrow \mathrm{Ha} \uparrow$

Thus, the basic hypothesis falls down and alternative hypotheses are accepted, concluding that the model is important in its entirety, independent variables such as non-performing loans and capital adequacy affect the variable variability of return on equity. To prove the hypothesis is found critical value through Fisher distribution.

$\mathrm{Fc}=\mathrm{F}_{\mathrm{k}, \mathrm{n}-\mathrm{k}-1, \alpha}=\mathrm{F}_{2,29,0.05}=3.3277$

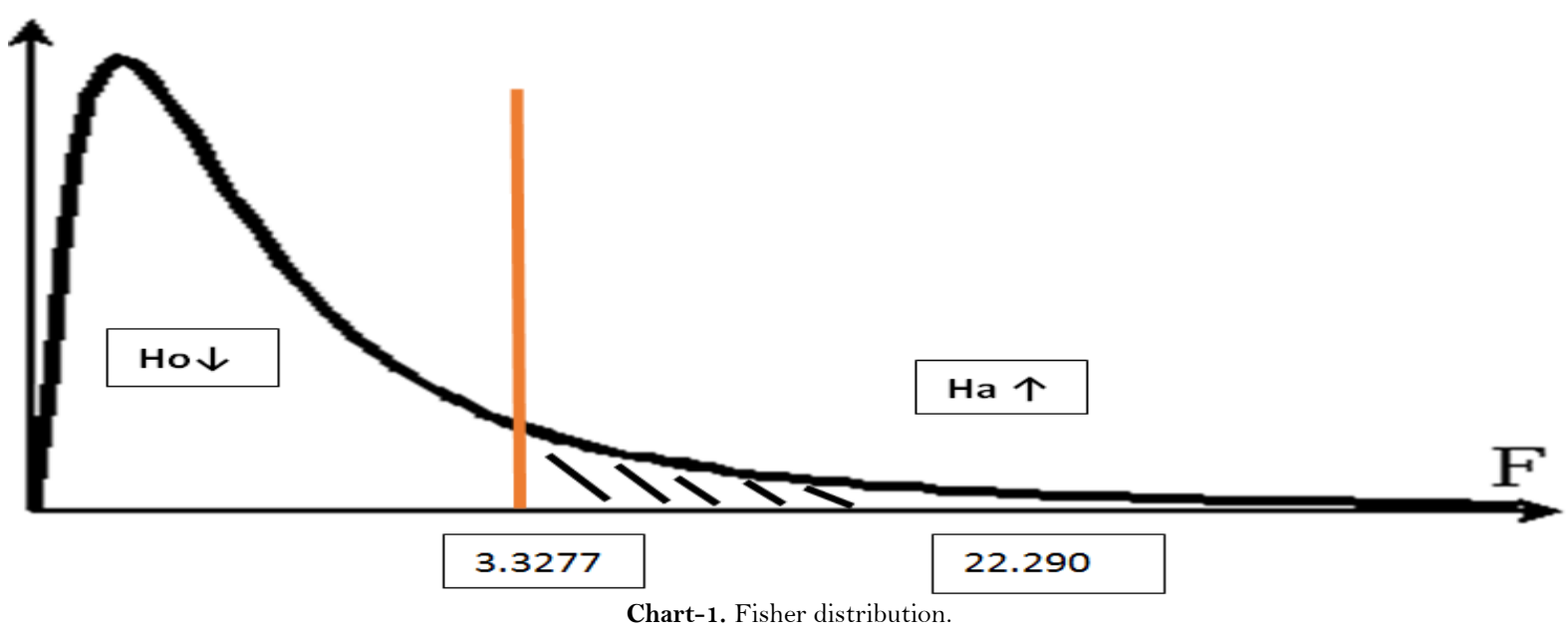




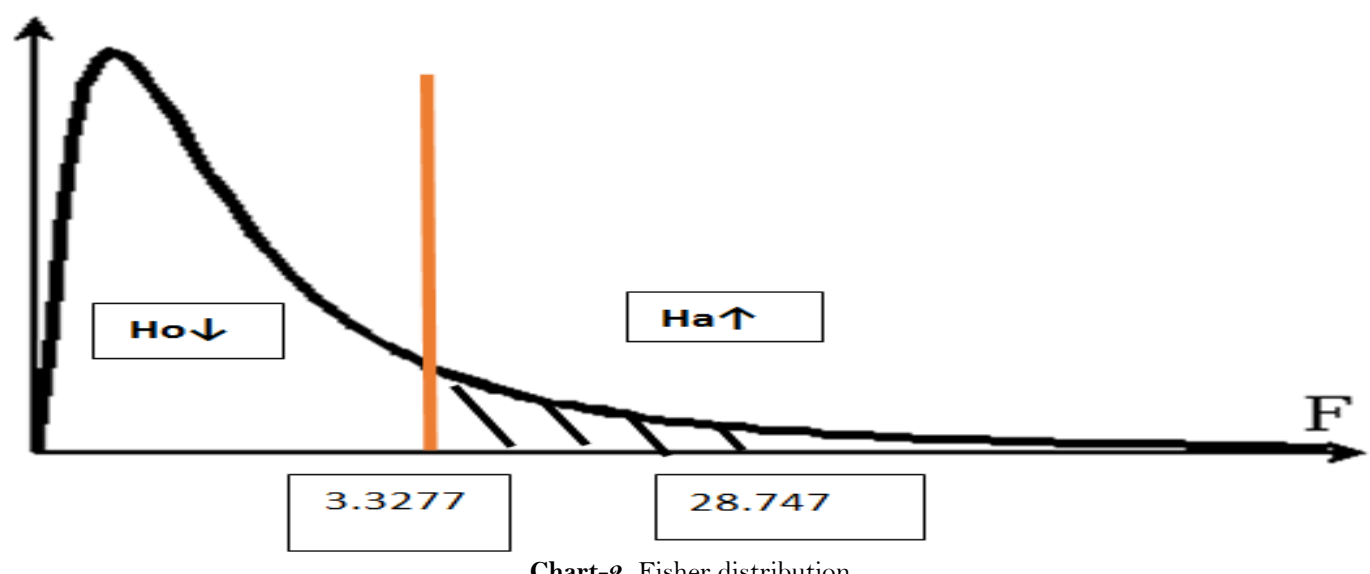

Based on the results in Tables 3 and 4, are also presented the estimated equations (for ROA and ROE) and the interpretation of the coefficients.

\begin{tabular}{|c|c|c|c|c|c|c|}
\hline \multicolumn{7}{|c|}{ Coefficients } \\
\hline \multirow{2}{*}{\multicolumn{2}{|c|}{ Model }} & \multicolumn{2}{|c|}{ Unstandardized Coefficients } & \multirow{2}{*}{\begin{tabular}{|l|} 
Standardized Coefficients \\
Beta \\
\end{tabular}} & \multirow[t]{2}{*}{$t$} & \multirow[t]{2}{*}{ Sig. } \\
\hline & & $\mathrm{B}$ & Std. Error & & & \\
\hline \multirow{3}{*}{1} & (Constant) & -3.641 & .979 & & -3.720 & .001 \\
\hline & NPL & -.018 & .007 & -.327 & -2.668 & .012 \\
\hline & CAR & .287 & .058 & .612 & 4.995 & .000 \\
\hline
\end{tabular}

First Equation Estimated:

$$
\hat{y}=-3.641-0.018 x_{1}+0.287 x_{2}
$$

If banks keep constant capital adequacy $\left(\mathrm{x}_{2}\right)$ and increase the rate of non-performing loans with a unit then return on assets will decrease to an average of 0,018 units. Thus, the growth with a credit risk unit will decrease the ROA by (0.018) to $1.8 \%$. If banks keep constant the problem of problem loans $\left(\mathrm{x}_{1}\right)$ and increase the capital adequacy rate with a unit then return on assets will increase to an average of 0.287 ie by $28.7 \%$. Thus, the increase with a capital adequacy unit will increase ROA by $28.7 \%$.

Table-3. Coefficient Table (ROE).

\begin{tabular}{l|l|l|l|l|l|l}
\hline \multirow{2}{*}{ Model } & \multicolumn{2}{|l|}{ Unstandardized Coefficients } & Standardized Coefficients & T & \multirow{2}{*}{ Sig. } \\
\cline { 3 - 8 } \multicolumn{2}{l|}{} & B & Std. Error & Beta & & \\
\hline \multirow{3}{*}{1} & (Constant) & -46.863 & 11.472 & & -4.085 & .000 \\
\cline { 2 - 8 } & NPL & -.265 & .080 & -.375 & -3.320 & .002 \\
\cline { 2 - 8 } & CAR & 3.680 & .675 & .617 & 5.456 & .000 \\
\hline
\end{tabular}

Second Equation Estimated:

$$
\hat{y}=-46.863-0.2658 x_{1}+3.680 x_{2}
$$

If banks keep constant capital adequacy $\left(\mathrm{x}_{2}\right)$ and raise non-performing loans with a unit $\left(\mathrm{x}_{1}\right)$ then return on equity will decrease to an average of 0.265 ie by $26.5 \%$. Thus, the growth of a credit risk unit will lead to a decline in ROE by $(26.5 \%)$. If banks keep the problem of non-performing loans constant $\left(\mathrm{x}_{1}\right)$ and increase the capital adequacy ratio with a unit $\left(\mathrm{x}_{2}\right)$ then the return on equity will increase to an average of 3,680. Thus, the increase with a capital adequacy unit will lead to an ROE increase of 3,680 units.

\section{Conclusions}

Based on the above analysis, it was concluded that credit risk has a significant impact on the profitability of commercial banks by verifying the hypothesis. Some specific endings were also achieved, such as:

- The results showed that there is a negative relationship between credit risk and profitability ROA and ROE, hence there is a correlation with profitability. Credit risk remains the most important risk faced by commercial banks, so its accurate measurement and credit risk management is of crucial importance. The relationship between credit risk and profitability was expected to be negative, given that the more unprofitable loans a bank has, the more the bank's profitability will be reduced.

- The results showed that capital adequacy has a positive relationship with two profitability variables with return on assets and return on equity. More importantly, capital adequacy has a return on equity with a higher statistical value than the return on assets. Capital adequacy ratio is one of the most important variables to measure the profitability of commercial banks, because a strong capital bank is able to pursue more efficiently and has more time and flexibility to dealing with problems arising 
from unexpected losses, thus increasing profitability. Thus, from the data analyzed in this study it is noticed that capital adequacy has value for profitability.

- Just as non-performing loans and capital adequacy influenced both models, such as return on assets and return on equity. In the ROA model, two independent variables account for $57.9 \%$ of changes in profitability of commercial banks, compared to ROE, which have a higher percentage of explained greater ROA than $64.2 \%$. Even the coefficient of correlation shows that ROE has a stronger linear relationship between ROE and NPL and also CAR while ROA has weaker connections. Thus, it is concluded that the return on equity is a more efficient profitability measurement than the return on assets. The empirical study concluded that there is a strong relationship between credit risk and profitability of commercial banks.

\section{Recommendations}

- Credit risk and capital adequacy are significant indicators of the profitability of commercial banks in Albania. It is recommended that focusing on improving or managing these indicators can result in increased profitability of commercial banks or their performance.

- Banks should ensure that they are constantly aware of the performance of the lending portfolio and normally of the weight they occupy in the overall portfolio in order to be ready to take appropriate measures to cope with the risk cases.

\section{References}

Alexandri, M. B. \& Santoso, T. I. (2015). Non-performing loan: Impact of internal and external factor (Evidence in Indonesia). International Journal of Humanities and Social Science Invention, 4(1): 8791.

Ameur, I. G. \& Mhiri, S. M. (2013). Explanatory factors of bank performance evidence from Tunisia. International Journal of Economics, Finance and Management, 2(1): 143-152.

Ali, K., Akhtar, M. F. \& Ahmed, H. Z. (2011). Bank specific and macroeconomic indicators of profitability empirical evidence from the commercial banks of Pakistan. International Journal of Business and Social Science, 2(6): $235-242$.

Abdullah, M.N., Parvez, K. \& Ayreen, S. (2014). Bank specific, industry specific and macroeconomic determinants of commercial bank profitability: A case of Bangladesh. World [online]. 4 (3). Available from: http://wjsspapers.com/static/documents/October/2014/7.\%20Nayeem\%20and\%20Kamruddin.pdf.

Awoke, E.T. (2014). Impact of credit risk on the performance of commercial banks in Ethiopia. ST. Mary's University, Ethiopia.

Chinoda, T. (2014). The determinants of commercial banks profitability in Zimbabwe (2009-2014). IOSR Journal of Economics and Finance, 5(6): 69-80.

Frederick, N.K. (2014). Factors affecting performance of commercial banks in Uganda. A case of domestic commercial banks. Proceedings of $25^{\text {th }}$ International Business Research Conference.

Gitau, P.M., Anyanga, W. \& Rotich, D.G. (2017). Effect of microeconomic factors on performance of listed commercial banks in Kenya. Strategic Journal.

Gizaw, M., Kebede, M. \& Sujata, S. (2015). The impact of credit risk on profitability performance of commercial banks in Ethiopia. African Journal of Business Management, 9(2): 59-66.

Gul, S., Irshad, F. \& Zaman, K. (2011).Factors affecting bank profitability in Pakistan. The Romanian Economic Journal, 1(39): 61-87.

Isik, I., Kyj, L. \& Kulalı, I. (2016). The anatomy of bank performance during transition: A separate efficient frontier analysis of Ukrainian banks. International Journal of Finance \& Banking Studies (2147-4486), 5(3): 1-31.

Ishak, I., Ismail, N., Razali, N.A., Bakar, R. \& Ramlan, H. (2016) Credit risk management and profitability of bank listed on Bursa Malaysia. International Symposium and Exhibition on Business and Accounting.

Kosmidou, K. (2008). The determinants of banks' profit in Greece during the period of EU financial integration. Tecnical University of Crete, Greece.

Li, F. \& Zou, Y. (2014). The impact of credit risk management on profitability of commercial banks: A study of Europe. Umea School of Business and Economics, Available from: http://www.diva-portal. org.

Naceur, B.S. (2003). The determinats of the Tunisian banking industry profitability: Panel evidence. University Libre De Tunis, Tunisia.

Ongore, V. O. \& Kusa, G. B. (2013). Determinants of financial performance of commercial banks in Kenya. International Journal of Economics and Financial Issues, 3(1): 237-252.

Pasiouras, F. \& Kosmidou, K. (2007). Factors influencing the profitability of domestic and foreign commercial banks in the European Union. Research in International Business and Finance, 21(2): 222-237.

Panda, M.R. \& Hota, D.P.K. (2014) An empirical study of the key determinants of competition in Indonesia banking sector. Global Journal of Commerce and Management Perspective. 
Saeed, M. S. \& Zahid, N. (2016). The impact of credit risk on profitability of the commercial banks. Journal of Business and Financial Affairs, 5(2): 192.

Sayılgan, G. \& Yıldırım, O. (2009). Determinants of profitability in Turkish banking sector: 2002-2007. International Research Journal of Finance \& Economics, 28: 207-2 14.

Suzuki, Y. \& Sastrosuwito, S. (2014) Post crisis Indonesian banking system profitability: Bank-specific, industry-specific and macroeconomic determinants. Ritsumeikan Asia Pacifik University, Japan.

Shrestha, R. (2017). The impact of credit risk management on profitability: Evidence from Nepalese commercial banks. Available from: https://ssrn.com/abstract=2938546. 